\title{
Syntheses and Hydrolysis of Basic and Dibasic Ampicillin Esters Tailored for Intracellular Accumulation
}

\author{
Isabelle Paternotte, ${ }^{\mathrm{a}, \mathrm{b}}$ Hua Juan Fan, ${ }^{\mathrm{a}}$ Pascal Scrève, ${ }^{\mathrm{a}}$ Michel Claesen, ${ }^{\mathrm{a}}$ \\ Paul M. Tulkens ${ }^{\mathrm{b}}$ and Etienne Sonveaux ${ }^{\mathrm{a}, *}$ \\ ${ }^{a}$ Unité de Chimie Pharmaceutique et de Radiopharmacie, Université Catholique de Louvain, \\ Avenue E. Mounier 73 p.b. 7340, B-1200 Bruxelles, Belgium \\ ${ }^{\mathrm{b}}$ Unité de Pharmacologie Cellulaire et Moléculaire, Université Catholique de Louvain, \\ Avenue E. Mounier 73 p.b. 7340, B-1200 Bruxelles, Belgium
}

Received 29 May 2000; accepted 4 October 2000

\begin{abstract}
Readily hydrolysable basic and dibasic esters of ampicillin were synthesised by alkylation of the carboxylate function of ampicillin to obtain prodrugs that may accumulate in cells and allow for an intracellular delivery of ampicillin (Fan et al., Bioorg. Med. Chem. Lett. 1997, 7, 3107). We found that the $\beta$-lactam ring cleavage and the hydrolysis of the ester function were competitive reactions. The prerequisite for biological activity of compounds of this type is therefore that ester hydrolysis proceeds faster than ring opening. Some synthesised compounds show promise as prodrugs since they displayed a reasonable stability and regenerate large quantities of bioactive ampicillin in broth. (C) 2001 Elsevier Science Ltd. All rights reserved.
\end{abstract}

\section{Introduction}

We described in a previous short communication ${ }^{1}$ the discovery of the cellular accumulation and intracellular antibacterial activity of basic ester prodrugs of ampicillin. These were original observations for $\beta$-lactams since, contrary to macrolides, fluoroquinolones and ansamycins, these antibiotics do not accumulate into cells and are therefore largely inefficient against most forms of intracellular infection. ${ }^{2,3} \mathrm{We}$ observed that important points to get intracellular accumulation of $\beta$-lactams were (i) the esterification of the carboxylate function and (ii) the presence of a protonable amino group in the antibiotic. We describe here the synthetic procedures giving access to monobasic prodrug esters of ampicillin which feature a marked cellular accumulation (the amino function is situated in the sidechain of the drug). Moreover, we illustrate in the particular case of ampicillin a general procedure allowing one to modify, in a bioreversible way, the carboxylate function of a drug into a basic ester (an amino function being present in the alcoholic part of this ester). Finally, we stress that the four-membered ring of $\beta$-lactam antibiotics is weakened by esterification. Very labile esters could be promising prodrugs whereas

*Corresponding author. Fax: +32-2-764-7363; e-mail: sonveaux@cmfa.ucl.ac.be slowly hydrolysing esters give ring-opened derivatives in phosphate buffer at $\mathrm{pH}$ 7.4.

\section{Results and Discussion}

\section{The context of the research: Design of esters of $\beta$-lactam} antibiotics

Benzylpenicillin methyl ester has been the most studied compound. Early works (reviewed by Hamilton-Miller ${ }^{4}$ ) showed that it was inactive in vitro as well as in vivo, at least in man. The interest in penicillin esters thus faded until double esters (like pivampicillin 1; Scheme 1) proved to be active in man. While benzylpenicillin methyl ester was not a substrate for esterases in larger mammals, its acetoxymethyl double ester was enzymatically hydrolysed and the generated benzylpenicillin hydroxymethyl ester spontaneously decomposed to benzylpenicillin and formaldehyde ${ }^{5}$ (Scheme 2).

It was discovered later on that human serum degraded benzylpenicillin methyl ester by opening of the $\beta$-lactam ring. Indeed, the ester was inactive not because its carboxylate function could not be regenerated, but because its $\beta$-lactam ring was cleaved first. ${ }^{6}$ Ring opening and ester cleavage are competitive reactions. The quickest process wins the race. Physico-chemical studies in buffers at 
physiological $\mathrm{pH}^{7-9}$ established the kinetic network presented in Scheme 3. The $\mathrm{pH}$ of 7.4 is situated in the base-catalysed domain of both ester hydrolysis and $\beta$-lactam ring opening. ${ }^{10}$ The productive pathway $\left(k_{\mathrm{p}}\right)$ liberates the active antibiotic while the non-productive pathway $\left(k_{\mathrm{np}}\right)$ yields inactive decomposition products. The generated $\beta$-lactam antibiotic itself eventually decomposes to ring-opened compounds $\left(k_{\mathrm{d}}\right)$. Page's team ${ }^{11}$ found that,
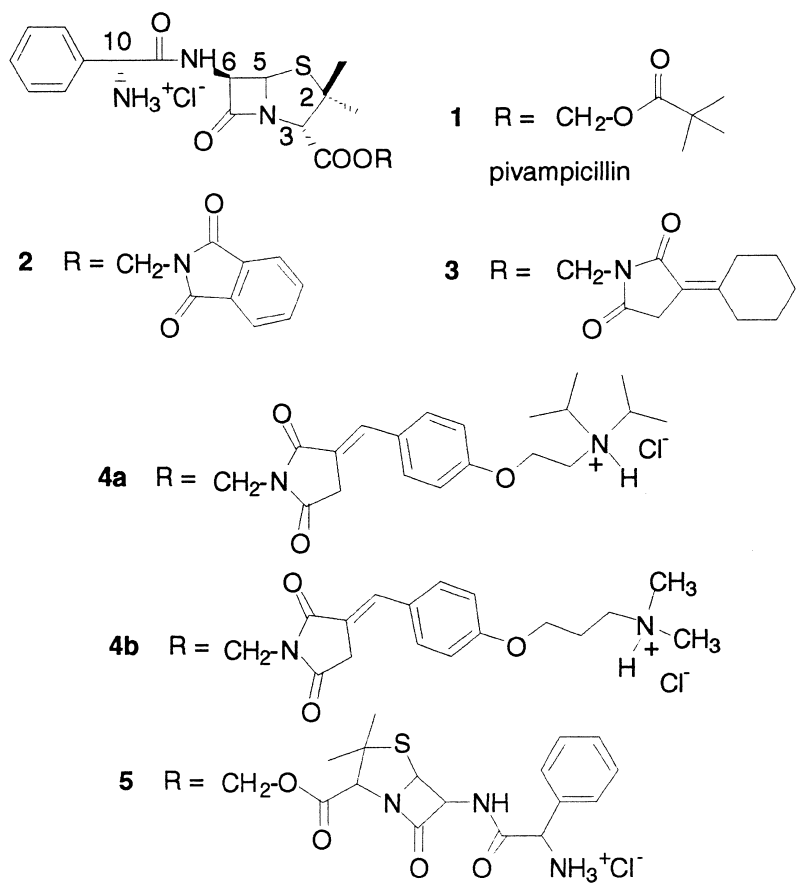

Scheme 1. Discussed ampicillin basic prodrugs.

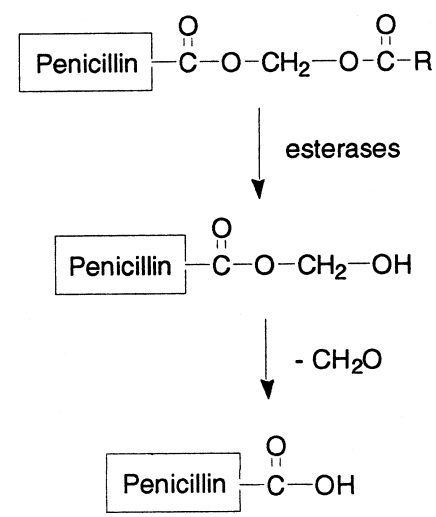

Scheme 2. Degradation path of acyloxymethyl esters of penicillins in human serum.

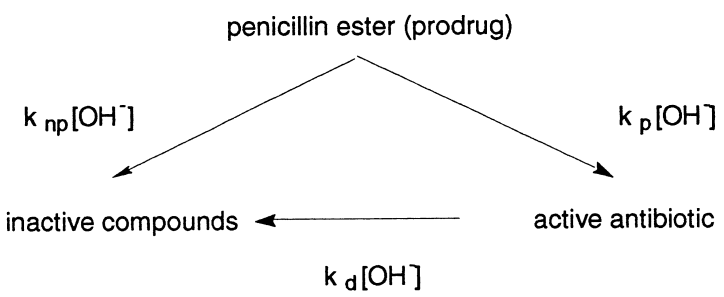

Scheme 3. Kinetic network describing the hydrolysis of penicillin esters at $\mathrm{pH}$ 7.4. for benzylpenicillin methyl ester, the sum $k_{\mathrm{p}}+k_{\mathrm{np}}$ was sixteen times larger than $k_{\mathrm{d}}$. The rate constant $k_{\mathrm{p}}$ being small in this case, this means that $k_{\mathrm{np}}$ equalled $16 k_{\mathrm{d}}$. In other words, the $\beta$-lactam ring of the ester was sixteen times more labile than that of the parent drug. This proved to be true even when $k_{\mathrm{p}}$ was larger than $k_{\mathrm{np}}$, i.e. in the case of efficient ester prodrugs. For example, pivampicillin and bacampicillin featured $k_{\mathrm{np}}$ s respectively twelve and 14 times larger than $k_{\mathrm{d} \cdot}{ }^{7,8}$

Why is the $\beta$-lactam ring of penicillins weakened by esterification of the carboxylate function? The ester group is more electron-withdrawing than the carboxylate group, which increases both the electrophilicity of the $\beta$-lactam carbonyl carbon and the leaving-group ability of the $\beta$-lactam amino group., ${ }^{7,12}$ This electronwithdrawing effect is reflected in the shift of the amine $\mathrm{p} K_{\mathrm{a}}$ from 5.2 for benzylpenicilloic acid to 3.2 for its methyl ester. ${ }^{11}$

Useful esters of $\beta$-lactam antibiotics have thus to feature the following kinetic characteristics: $k_{\mathrm{p}}>k_{\mathrm{np}}=12-16 k_{\mathrm{d}}$. The $k_{\mathrm{p}} / k_{\mathrm{np}}$ competition has to be pushed in the good direction by synthesising so called 'activated esters', i.e. labile esters. In the basic $\mathrm{pH}$ range, they have to be at least 20-30 times more labile than the $\beta$-lactam ring of the parent compound. However, a decent half-life of the ester prodrugs in the serum has to be maintained. These opposite requirements assign intrinsic limits to our approach.

Activated esters are usually obtained by enhancing the leaving group capability of the alcohol moiety by the mesomeric effect (e.g. p-nitrophenol) or the inductive effect (e.g. trifluoroethanol). Aromatic esters of $\beta$-lactam antibiotics being difficult to synthesise, we considered ampicillin esters of the type AMPI-COOCH${ }_{2} \mathrm{X}$. There are severe limitations on X. It cannot be a carbonyloxy group (e.g. as in pivampicillin 1), owing to the required resistance to human serum esterases. Compound $\mathbf{5}$ should be an exception (as stated before, the methyl ester of benzylpenicillin is not a good substrate for human esterases). The $\mathrm{X}$ function cannot be either an alkoxy $\mathrm{R}^{\prime} \mathrm{O}$ - or a carbonylamino $\mathrm{R}^{\prime} \mathrm{CON}\left(\mathrm{R}^{\prime \prime}\right)$ - group because $\alpha$-carboxymethyl ethers and $\alpha$-carboxymethylamides spontaneously cleave by an $\mathrm{S}_{\mathrm{N}} 1$ mechanism that does not require base catalysis, just like $\alpha$-chloromethyl ethers. This uncatalysed process renders impossible the controlled release of ampicillin from a stable prodrug solution. ${ }^{13,14}$ To avoid a chloromethyl ether type of fission, the lone pair of $\mathrm{X}$ has to be strongly involved in mesomery. That is why we considered imide functions $\left(\mathrm{X}=\mathrm{N}(\mathrm{COR})_{2}\right)$, i.e. compounds 2-4. This type of ester was known to be much more rapidly hydrolysed than an ethyl ester at $\mathrm{pH} 7.4 .{ }^{15}$

Compounds $\mathbf{1}-\mathbf{3}$ and $\mathbf{5}$ are basic owing to the amino function present in the phenylglycine sidechain of ampicillin. Compounds $\mathbf{4 a , b}$ bear an additional amino function in the alcoholic part of the ester. Attachment of this alcoholic part to $\beta$-lactam antibiotics other than ampicillin would thus render them basic as well. Compounds $\mathbf{4 a}, \mathbf{b}$ were therefore synthesised to enlarge the 
scope of the work. Moreover, if a monobasic molecule can theoretically be concentrated a hundred times in acidic organelles, dibasic ones could reach a theoretical maximum enrichment of ten thousand, based on the $\mathrm{pH}$ effect only. ${ }^{16}$ The structural characteristics we wanted for the basic alcoholic part of these esters were (i) the absence of chiral centre (to avoid epimerisation problems when working with chiral synthons or the obtention of a mixture of diastereoisomeric prodrugs when using racemic synthons), (ii) the lack of protection of the amino function (protections are difficult to remove in the presence of the $\beta$-lactam ring) and (iii) a good lipophilicity (to enhance the rate of cellular penetration). These requirements were met with $\mathbf{4 a , b}$.

Synthesis. The synthesis of $\mathbf{3}$ and $\mathbf{4 a , b}$ are sketched in Scheme 4. A key reagent was the phosphorus ylid obtained by Michael addition of triphenyl (or tributyl) phospine on maleimide. ${ }^{17}$ The double bond of $7 \mathbf{a}$ and $7 \mathbf{b}$, obtained by the Wittig reaction, has the $E$ configuration. Stabilised ylids usually indeed give the thermodynamically more stable olefin. ${ }^{18,19}$ The $Z$ configuration of these succinimide derivatives would have a higher energy content due to the steric clash between the imide carbonyl and the phenyl ring, impairing mesomery. By the way, the methylene of the imide ring of the $E$ isomer sits in the deshielding area of the phenyl substituent, so that its chemical shift goes up by $0.3-0.4 \mathrm{ppm}$ relative to the corresponding methylene of $\mathbf{1 0}$, the synthon used to obtain 3. Moreover, the olefinic hydrogen of $7 \mathbf{a}$ or $\mathbf{7 b}$ sits in the deshielding area of the carbonyl anisotropy double cone: the chemical shift of this hydrogen (7.53 ppm for $7 \mathbf{a}$ and 7.64 for $7 \mathbf{b}$ ) fits well with the value calculated by additive rules ( $7.2 \mathrm{ppm}$ for the $E$ isomer versus 6.7 for the $Z$ one $^{20}$ ).

The $N$-hydroxymethyl function of $\mathbf{8 a}, \mathbf{b}$, obtained by condensation with formaldehyde, is incompatible with a free amino group, because it would promote the ionisation of the $\mathrm{OH}$ group and the expulsion of the imide anion. ${ }^{21}$ That is why the hydrobromide was engaged in the condensation with formaldehyde, instead of the free amine.

The bulky diisopropylamino function was used to prevent auto-alkylation of 9a. We observed indeed that $\mathrm{N}$-bromomethylphthalimide quantitatively alkylated triethylamine

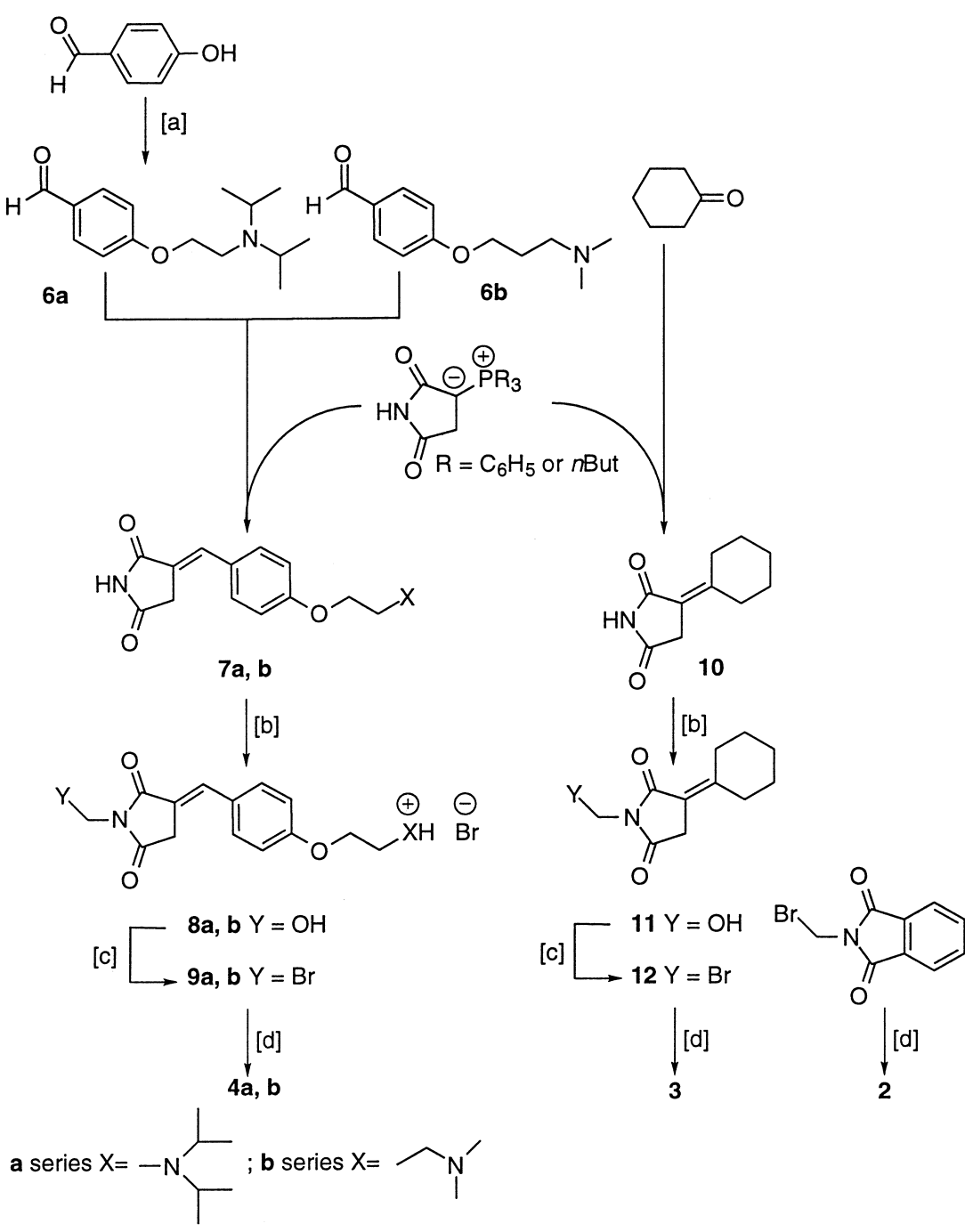

Scheme 4. Synthesis of 4a: [a] (1) $\mathrm{Cs}_{2} \mathrm{CO}_{3}$, DMF; (2) $\mathrm{Cl}-\mathrm{CH}_{2}-\mathrm{CH}_{2}-\mathrm{N}\left[\mathrm{CH}\left(\mathrm{CH}_{3}\right)_{2}\right]_{2}$; [b] (1) $\mathrm{HBr}$; (2) aqueous $\mathrm{CH}_{2} \mathrm{O}$; [c] $\mathrm{PBr}$; [d] see Scheme 5. 
(DMF, room temperature, $24 \mathrm{~h}$ ), while diisopropylethylamine did not react. We recognised afterwards, when synthesising $\mathbf{9 b}$, that the presence of two isopropyl groups on the amine function was not an absolute requirement, as long as the amine remained protected by protonation till the coupling with ampicillin. During the coupling itself, a competition was established between autoalkylation and alkylation of the carboxylate function of ampicillin but this latter reaction proved to be the fastest.

The reaction of $N$-bromomethylimides with ampicillin (on way to 2-4) or of diiodomethane with ampicillin (on way to 5) required the protection of the amino function of the phenylglycine sidechain. This was done by in situ condensation with benzaldehyde (Scheme 5). We verified that alkylation in these conditions took place on the carboxylate function of ampicillin (and not on its amino function) by $N$-acylating compound $\mathbf{2}$ with acetic anhydride in $90 \%$ yield. The acylated derivative featured two amide $\mathrm{NH}$ protons in ${ }^{1} \mathrm{H}$ NMR (the 6-CHNH and the 10-CHNH; see Scheme 1 for atom numbering).

A concern was also the possible epimerisation of the phenylglycine sidechain (at 10-C) due to the transient formation of its imine derivative by condensation with benzaldehyde, but both the ${ }^{1} \mathrm{H}$ and ${ }^{13} \mathrm{C}$ spectra corresponded to a single diastereoisomer. Ampicillin epimers at $10-\mathrm{C}$ are distinguishable even when using a $60 \mathrm{MHz}$ instrument. ${ }^{22}$ In fact, aldehydes and ketones are known to react with ampicillin not to give an imine but an imidazilidinone ring, ${ }^{23,24}$ so that the $\alpha$-hydrogen of the phenylglycine sidechain is not acidified, as should be the case if an imine was formed.

Hydrolysis of the esters. Imidomethyl esters of ampicillin are biologically active in cellular culture, as reported in our previous short communication. ${ }^{1}$ This means that, at least in this medium, $k_{\mathrm{p}}$ was larger than $k_{\mathrm{np}}$, or of similar magnitude. The half-lives of compounds $\mathbf{1}-\mathbf{5}$ $\left(=0.693 /\left(k_{\mathrm{p}}+k_{\mathrm{np}}\right)\right)$, in phosphate buffer, $\mathrm{pH} 7.4,37^{\circ} \mathrm{C}$, were determined by HPLC (Table 1). The hydrolysis was base-catalysed above $\mathrm{pH} 5.5$ and followed first-order kinetics. The rate increased with the electron-withdrawing power of the alcoholic part of the ester (compare 2 with 3), in agreement with the base-catalysed mechanism. The HPLC trace of the mixture obtained after pivampicillin $\mathbf{1}$ and prodrugs $\mathbf{2}$ and $\mathbf{3}$ stayed in the buffer during 1 half-life is shown in Figure 1(a). The correlation between the decrease in concentration of the prodrugs and the increase in concentration of released ampicillin is also shown (Fig. 1(b)). Ampicillin itself was only marginally degraded in these conditions $\left(t_{1 / 2}\right.$ of ampicillin was $2144 \mathrm{~min}$ ). The $k_{\mathrm{p}}: k_{\mathrm{np}}$ competition was in favour of ampicillin for quickly hydrolysing compounds $\mathbf{1}, \mathbf{2}, \mathbf{5}$ (ratios of ampicillin versus ring opened products of $66: 34,68: 32$ and 82:18, respectively). Less readily hydrolysing compounds, $\mathbf{3}$ and $\mathbf{4 a}$, generated a lower amount of ampicillin (ratios of 29:71 and 41:59, respectively: $k_{\mathrm{np}}>k_{\mathrm{p}}$ ). The addition of the released formaldehyde to ampicillin, giving an imidazolidinone ring, ${ }^{25}$ was not an important side reaction in our conditions.

That $\beta$-lactam ring opening was a major degradation pathway was shown by LC-MS-MS (Tables 3-5).

Table 1. Half-lives (min) of compounds 1-5

\begin{tabular}{lc}
\hline Compound & Half-life $^{\mathrm{a}}(\mathrm{min})$ \\
\hline Pivampicillin $\mathbf{1}$ & 92 \\
$\mathbf{2}$ & 62 \\
$\mathbf{3}$ & 191 \\
$\mathbf{4 a}$ & 143 \\
$\mathbf{5}$ & 26 \\
\hline
\end{tabular}

aPhosphate buffer $(0.02 \mathrm{M}, \mathrm{NaCl} 0.15 \mathrm{M}$, ethanol $1 \% \mathrm{v} / \mathrm{v}, \mathrm{pH} 7.4$, $\left.37^{\circ} \mathrm{C}\right)$.

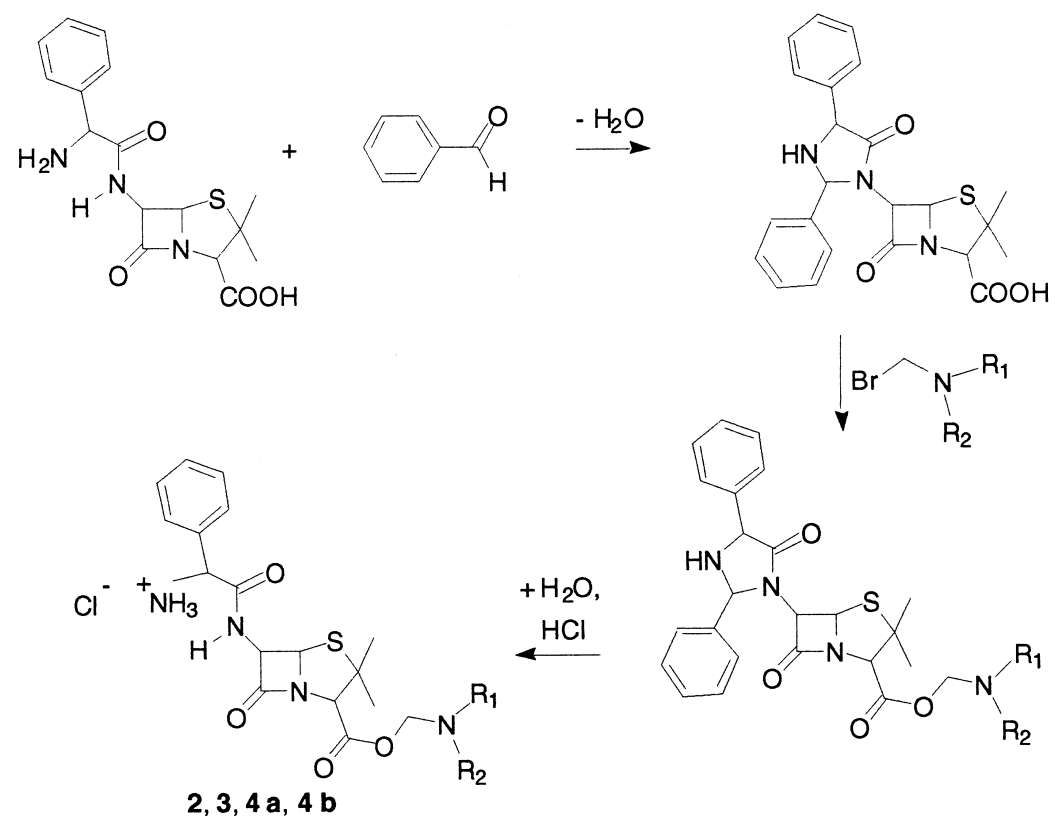

Scheme 5. Synthesis of ampicillin esters 2-4. 
Samples of 1, 2 and $\mathbf{3}$ were kept in an ethanol:water mixture $(1: 4, \mathrm{v} / \mathrm{v})$ for 15 days at room temperature, and then analysed. The obtained compounds are sketched in Scheme 6. Besides the starting prodrugs and ampicillin, 5- $R$ and 5- $S$ ampicilloic acid esters 13 were detected,
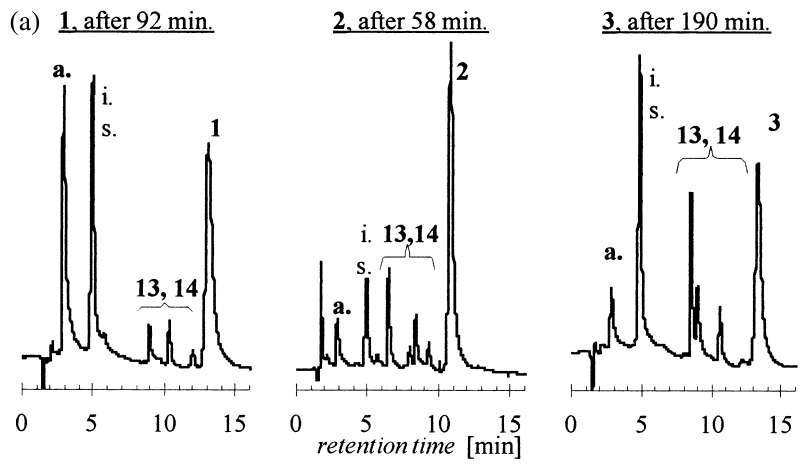

(b)

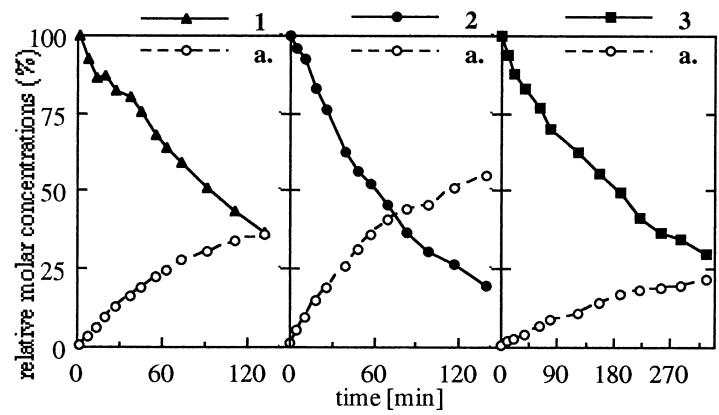

Figure 1. Hydrolysis of pivampicillin (1), 2 and $\mathbf{3}(1 \mathrm{mM})$ in phosphate buffer $\left(0.02 \mathrm{M}, \mathrm{NaCl} 1.5 \mathrm{M}, \mathrm{pH} 7.4,1 \%\right.$ ethanol v/v) at $37^{\circ} \mathrm{C}$. (a) HPLC traces of the reaction mixtures after ca. a half-life of each compound (UV detection at $220 \mathrm{~nm}$, uncorrected for differences on molar adsorptivity coefficients). a. is ampicillin; i.s. is the internal standard, benzamide; 13 (two epimers) and $\mathbf{1 4}$ are identified in Scheme 6. (b) Evolution of the relative molar concentrations (\%) of the starting compound and of released ampicillin (a.) as a function of time.

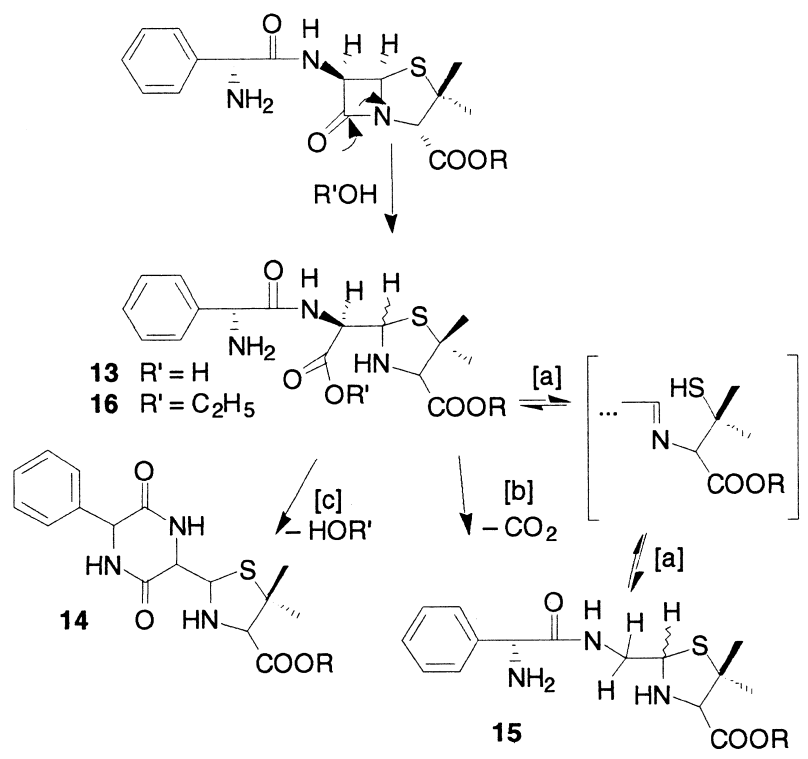

Scheme 6. $\beta$-Lactam ring opening products identified by LC-MS-MS after prodrugs 1,2 or $3(0.2 \mathrm{mg} / \mathrm{mL})$ were kept 15 days at room temperature in an ethanol:water mixture (1:4). $\mathrm{R}$ has the same meaning as in Scheme 1. resulting from the opening of the $\beta$-lactam ring by water and epimerisation via an intermediate imine (equilibrium [a]). 5- $R, 5-S$ ampicilloic acid esters 15 (pathway [b]) resulted from the decarboxylation of $\mathbf{1 3}$ (see refs 26 and 27 for mechanistic details). The ampicilloic acid disymmetric double esters 16, resulting from the $\beta$ lactam ring opening by ethanol, and the piperazine-2,5diones 14 were also found. The rearrangement of ampicilline itself in a piperazine-2,5-dione is a known reaction. ${ }^{28}$

The hydrolysis of active esters and the ring opening of $\beta$-lactams are subject to general acid-base and nucleophilic catalysis. ${ }^{10}$ Enzymes may also accelerate both reactions. To obtain a first information on the usefulness of our compounds in terms of effective release of the parent antibiotic, we measured their antibacterial potency in tryptic soy broth, in comparison with ampicillin. Table 2 gives their minimum inhibitory concentrations (MICs) against $S$. aureus in this culture medium. The determination entails a $24 \mathrm{~h}$ incubation at $37^{\circ} \mathrm{C}$, which should allow both productive $\left(k_{\mathrm{p}}\right)$ and non-productive disappearance of the prodrugs $\left(k_{\mathrm{np}}\right)$. The MICs of $\mathbf{2}$ and $\mathbf{5}$ were of the same order of magnitude as that of ampicillin, indicating that a large part of these prodrugs followed a productive degradation pathway. Conversely, slower hydrolysing esters 3 and 4a displayed a lower activity than ampicillin, suggesting that, for these compounds, $k_{\mathrm{np}}$ indeed overwhelmed $k_{\mathrm{p}}$. Results along the same line were obtained after ageing of the solutions. The MICs had a tendency to increase, probably due to the spontaneous degradation of the released ampicillin.

\section{Perpectives}

The method we used to synthesise basic and dibasic esters of ampicillin is general and could be applied to other penicillins and cephalosporins. The ester function of the most promising $\beta$-lactam prodrugs is more labile than their four-membered ring. Further work is in progress to fully characterise the cellular accumulation of these esters and to check their fate in human blood as well as their activity in vivo.

Table 2. Minimum inhibitory concentrations (MICs) of compounds 1-5

\begin{tabular}{lccccc}
\hline \multirow{2}{*}{ Compound } & \multicolumn{2}{c}{$\mathrm{MIC}^{\mathrm{a}}$} & & \multicolumn{2}{c}{$\mathrm{MIC}^{\mathrm{b}}$} \\
\cline { 2 - 3 } \cline { 6 - 6 } & $\mu \mathrm{M}$ & $\mu \mathrm{g} / \mathrm{mL}$ & & $\mu \mathrm{M}$ & $\mu \mathrm{g} / \mathrm{mL}$ \\
\hline Ampicillin & $0.3 \pm 0.1$ & $0.1 \pm 0.05$ & & $0.5 \pm 0.1$ & $0.2 \pm 0.05$ \\
Pivampicillin 1 & $0.5 \pm 0.1$ & $0.25 \pm 0.05$ & & $0.6 \pm 0.1$ & $0.3 \pm 0.05$ \\
$\mathbf{2}$ & $0.4 \pm 0.1$ & $0.2 \pm 0.05$ & & $0.5 \pm 0.1$ & $0.3 \pm 0.05$ \\
$\mathbf{3}$ & $1.2 \pm 0.3$ & $0.7 \pm 0.2$ & & $1.2 \pm 0.3$ & $0.7 \pm 0.2$ \\
$\mathbf{4 a}$ & $1.2 \pm 0.4$ & $1 \pm 0.3$ & & $1.2 \pm 0.4$ & $1 \pm 0.3$ \\
$\mathbf{5}$ & $0.2 \pm 0.1$ & $0.15 \pm 0.05$ & & $0.4 \pm 0.1$ & $0.3 \pm 0.05$
\end{tabular}

against Staphylococcus aureus using freshly prepared solutions. The MIC is defined as the lowest concentration of antibiotic giving no visible bacterial growth (naked-eye examination) after $24 \mathrm{~h}$ incubation at $37^{\circ} \mathrm{C}$ in tryptic soy broth $37^{\circ} \mathrm{C}$ (initial pH 7.4), inoculum $10^{6} \mathrm{CFU}$ $\mathrm{mL}$, dilutions tested: $0.05 ; 0.075 ; 0.1 ; 0.15 ; 0.2 ; 0.25 ; 0.3 ; 0.4 ; 0.5 ; 0.7$; $1 ; 1.5 \mu \mathrm{g} / \mathrm{mL}$.

bame determination using an aged solution ( $24 \mathrm{~h}$ standing in tryptic soy broth (pH 7.4) at $\left.37^{\circ} \mathrm{C}\right)$. 


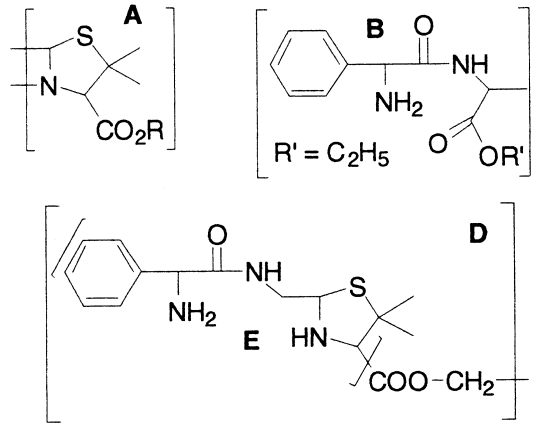

Scheme 7. Principal fragments observed by LC-MS-MS.

Table 3. LC-MS-MS determination of the products of solvolysis of 1 (15 days, rt, ethanol:water mixture, 1:4 v/v)

\begin{tabular}{lrcccc}
\hline Product & $\begin{array}{c}\text { Retention } \\
\text { time }^{\mathrm{b}}\end{array}$ & Epimer $^{\mathrm{c}}$ & {$[\mathrm{M}+\mathrm{H}]^{+}$} & $\begin{array}{c}\text { Main } \\
\text { fragment }^{\mathrm{d}}\end{array}$ \\
\hline Ampicillin & 5.6 & - & 350 & {$[\mathbf{A}+\mathrm{H}]^{+}$} & 160 \\
$\mathbf{1 3}^{\mathrm{a}}$ & 13.4 & 14.2 & 482 & {$\left[\mathrm{M}+\mathrm{H}-\mathrm{CO}_{2}\right]^{+}$} & 438 \\
$\mathbf{1 4}^{\mathrm{a}}$ & 17.1 & - & 464 & {$[\mathrm{~A}+\mathrm{H}]^{+}$} & 274 \\
1 & 21.3 & - & 464 & {$[\mathrm{~A}+\mathrm{H}]^{+}$} & 274 \\
$\mathbf{1 5}^{\mathrm{a}}$ & 21.7 & 23.0 & 438 & {$[\mathbf{E}]^{+}$} & 278 \\
$\mathbf{1 6}^{\mathrm{a}}$ & 27.0 & - & 510 & {$[\mathbf{B}+2 \mathrm{H}]^{+}$} & 237 \\
\hline
\end{tabular}

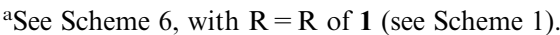

${ }^{b}$ In min. See Experimental.

${ }^{\mathrm{c}}$ Retention time of the epimer (see Scheme 6).

${ }^{\mathrm{d}}$ See Scheme 7.

Table 4. LC-MS-MS determination of the products of solvolysis of 2 (15 days, rt, ethanol:water mixture, 1:4 v/v)

\begin{tabular}{lrcccc}
\hline Product & $\begin{array}{c}\text { Retention } \\
\text { time }\end{array}$ & Epimer & & {$[\mathrm{M}+\mathrm{H}]^{+}$} & $\begin{array}{c}\text { Main } \\
\text { fragment }^{\mathrm{e}}\end{array}$ \\
\hline Ampicillin & 5.4 & - & 350 & {$[\mathbf{A}+\mathrm{H}]^{+}$} & 160 \\
$\mathbf{1 5}^{\mathrm{a}}$ & 7.5 & 8.1 & 324 & {$\left[\mathrm{M}+\mathrm{H}-\mathrm{NH}_{3}\right]^{+}$} & 307 \\
$\mathbf{1 6}^{\mathrm{a}}$ & 9.4 & 10.0 & 396 & {$[\mathbf{B}+2 \mathrm{H}]^{+}$} & 237 \\
$\mathbf{1 3}^{\mathrm{b}}$ & 12.0 & 12.6 & 527 & {$\left[\mathrm{M}+\mathrm{H}-\mathrm{CO}_{2}\right]^{+}$} & 483 \\
$\mathbf{1 4}^{\mathrm{b}}$ & 15.7 & - & 509 & {$[\mathbf{A}+\mathrm{H}]^{+}$} & 319 \\
$\mathbf{2}$ & 18.4 & - & 509 & {$[\mathbf{A}+\mathrm{H}]^{+}$} & 319 \\
$\mathbf{1 5}^{\mathrm{b}}$ & 18.8 & 19.5 & 483 & {$[\mathbf{D}]^{+}$} & 336 \\
$\mathbf{1 6}^{\mathrm{b}}$ & 21.7 & - & 555 & {$[\mathbf{A}+\mathrm{H}]^{+}$} & 319 \\
\hline
\end{tabular}

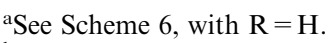

${ }^{b}$ See Scheme 6, with $\mathrm{R}=\mathrm{R}$ of 2 (see Scheme 1).

'In min. See Experimental.

${ }^{\mathrm{d}}$ Retention time of the epimer (see Scheme 6).

'See Scheme 7.

Table 5. LC-MS-MS determination of the products of solvolysis of 3 (15 days, rt, ethanol:water mixture, 1:4 v/v)

\begin{tabular}{lccccc}
\hline Product & $\begin{array}{c}\text { Retention } \\
\text { time }^{\mathrm{b}}\end{array}$ & Epimer $^{\mathrm{c}}$ & {$[\mathrm{M}+\mathrm{H}]^{+}$} & $\begin{array}{c}\text { Main } \\
\text { fragment }^{\mathrm{d}}\end{array}$ \\
\hline Ampicillin & 5.6 & - & 350 & {$[\mathbf{A}+\mathrm{H}]^{+}$} & 160 \\
$\mathbf{1 3}^{\mathrm{a}}$ & 14.0 & 14.2 & 559 & {$\left[\mathrm{M}+\mathrm{H}-\mathrm{CO}_{2}\right]^{+}$} & 515 \\
$\mathbf{1 4}^{\mathrm{a}}$ & 18.5 & - & 541 & {$[\mathbf{A}+\mathrm{H}]^{+}$} & 351 \\
$\mathbf{3}$ & 22.5 & - & 541 & {$[\mathbf{A}+\mathrm{H}]^{+}$} & 351 \\
$\mathbf{1 5}^{\mathrm{a}}$ & $23.4-25$ & & 515 & {$[\mathbf{D}]^{+}$} & 336 \\
$\mathbf{1 6}^{\mathbf{a}}$ & 27.7 & - & 587 & {$[\mathbf{A}+\mathrm{H}]^{+}$} & 351 \\
\hline
\end{tabular}

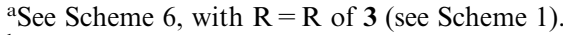

${ }^{\mathrm{b}}$ In min. See Experimental.

${ }^{\mathrm{c}}$ Retention time of the epimer (see Scheme 6).

${ }^{\mathrm{d}}$ See Scheme 7.

\section{Experimental}

\section{General}

Solvents and reagents. Unless otherwise stated, commercially available solvents and reagents were used. 4-[3-(Dimethyl-amino)propoxy]benzaldehyde was from Aldrich Co.

IR spectroscopy. A Perkin-Elmer 457 spectrophotometer was used.

NMR spectroscopy. NMR spectra were recorded on a Bruker AC-300 instrument. Chemical shifts are reported in $\delta$ values (ppm) with TMS as an internal reference. Splitting patterns are indicated as s (singlet), d (doublet), $\mathrm{t}$ (triplet), q (quartet), $\mathrm{m}$ (multiplet). For the ${ }^{13} \mathrm{C}$ data, only selected signals are reported. The numbering of the carbons is indicated in Scheme 1.

HPLC analysis. Chromatographies were performed on a Gilson apparatus, injection loop of $100 \mu \mathrm{L}$, using a precolumn filled with reversed phase $\mathrm{C}_{18}$ powder and a reversed phase $\mathrm{C}_{18}$ column (Adsorbosphere Alltech, $15 \mathrm{~cm} \times 4.6 \mathrm{~mm}$ ) at a flow rate of $1 \mathrm{~mL} / \mathrm{min}$. Eluent A (acetonitrile:methanol:aqueous buffer, 10:10:80) was passed during $2 \mathrm{~min}$, then a linear gradient of eluent $\mathrm{B}$ (same components, 50:20:30) in eluent $\mathrm{A}$ from 0 to $100 \%$, over 5 min. The washing with $100 \%$ eluent B was maintained for $20 \mathrm{~min}$. The aqueous buffer was an ammonium formate buffer, $0.02 \mathrm{M}$ (adjusted at $\mathrm{pH} 5$ with formic acid). The UV detection was performed at $220 \mathrm{~nm}$. The $\varepsilon_{220} \mathrm{~s}$ were determined: ampicillin, 6675; pivampicillin 1, 6625; compound 2, 43305; 3, 12526; 4a, $168021 \mathrm{~mol}^{-1} \mathrm{~cm}^{-1}$. The hydrolysis of the samples $(100 \mu \mathrm{L})$ was stopped by addition of $7 \mu \mathrm{L}$ of $\mathrm{HCl}, 0.5 \mathrm{M}$ (end $\mathrm{pH}=5$ ). The samples were placed in dry ice (for $3 \mathrm{~h}$ maximum) till the injection was performed.

LC-MS-MS analysis. These were run on a Thermo Separation Product AS-3000 chromatograph (column: Adsorphosphere Alltech, $25 \mathrm{~cm} \times 2.1 \mathrm{~mm}$ ), coupled with a TSQ-7000 mass spectrometer working in the APCI mode (atmospheric pressure chemical ionisation). A linear gradient of eluent $\mathrm{B}$ in eluent $\mathrm{A}$ was used, from 0 to $100 \%$ over $10 \mathrm{~min}$ (flow rate $0.2 \mathrm{~mL} / \mathrm{min}$ ). The eluent and buffer were the same as above. We realised first an LC-MS experiment to set the parameters for the LCMS-MS analysis, performed the same day.

Ampicillin phthalimidomethyl ester, hydrochloride (2). A mixture of ampicillin trihydrate $(2 \mathrm{~g}, 5 \mathrm{mmol})$, potassium bicarbonate $(0.5 \mathrm{~g}, 5 \mathrm{mmol})$, benzaldehyde $(1 \mathrm{~mL}$, $10 \mathrm{mmol})$ and DMF $(50 \mathrm{~mL})$ was stirred at $0^{\circ} \mathrm{C}$ for $12 \mathrm{~h}$ to give an imidazolidinone (see Scheme 5), not isolated. Anhydrous magnesium sulfate $(1.2 \mathrm{~g}, 10 \mathrm{mmol}$, heated at $800{ }^{\circ} \mathrm{C}$ for $24 \mathrm{~h}$ ) was added to trap water, and, after a few min, a further equivalent of potassium bicarbonate $(0.5 \mathrm{~g}, 5 \mathrm{mmol})$ and $N$-(bromomethyl)phthalimide $(1.2 \mathrm{~g}$, $5 \mathrm{mmol}$ ). After stirring $24 \mathrm{~h}$ at $0^{\circ} \mathrm{C}$, the mixture was poured into cold water $(80 \mathrm{~mL})$ and extracted with ethyl acetate $(3 \times 60 \mathrm{~mL})$. The organic extract was washed with brine $(3 \times 50 \mathrm{~mL})$, dried over magnesium sulfate and filtered. The filtrate, after evaporation under vacuum, was 
stirred at $-15^{\circ} \mathrm{C}$ for $20 \mathrm{~min}$ in a $1: 1$ mixture of acetonitrile and water $(40 \mathrm{~mL})$ adjusted at $\mathrm{pH} 2.5$ with $0.5 \mathrm{M}$ $\mathrm{HCl}$. Water was added $(40 \mathrm{~mL})$ and the $\mathrm{pH}$ was adjusted to 5.0 by adding potassium bicarbonate. This solution was freed of acetonitrile by evaporation under vacuum, washed with ethyl acetate $(4 \times 50 \mathrm{~mL})$ and saturated with sodium chloride. The formed precipitate was collected by filtration and washed with dichloromethane and ether. Yield $1.9 \mathrm{~g}, 76 \%, \mathrm{mp} 159-160^{\circ} \mathrm{C}$. Elemental analysis $\mathrm{C}_{25} \mathrm{H}_{25} \mathrm{ClN}_{4} \mathrm{O}_{6} \mathrm{~S} \cdot \mathrm{H}_{2} \mathrm{O}$ : calcd $\mathrm{C}, 53.33, \mathrm{H}, 4.83$, $\mathrm{N}, 9.95, \mathrm{Na}, 0.0$; found $\mathrm{C}, 53.38, \mathrm{H}, 4.94, \mathrm{~N}, 9.79, \mathrm{Na}$, $0.045 .{ }^{1} \mathrm{H}$ NMR $\left(\mathrm{CD}_{3} \mathrm{OD}\right): \delta=1.39$ and $1.41(2 \times \mathrm{s}, 6 \mathrm{H}$, $\left.2 \times \mathrm{CH}_{3}\right), 4.40(\mathrm{~s}, 1 \mathrm{H}, 3-\mathrm{CH}), 5.07(\mathrm{~s}, 1 \mathrm{H}, 10-\mathrm{CH}), 5.46$ and $5.57(2 \times \mathrm{d}, J=4.2 \mathrm{~Hz}, 2 \mathrm{H}, 5-$ and $6-\mathrm{CH}), 5.73$ and $5.78\left(2 \times \mathrm{d}, J=10.6 \mathrm{~Hz}, 2 \mathrm{H}\right.$, diastereotopic $\mathrm{H}^{\prime} \mathrm{s}$ of $\mathrm{O}-\mathrm{CH}_{2}-$ $\mathrm{N}), 7.47\left(\mathrm{~m}, 5 \mathrm{H}, \mathrm{C}_{6} \mathrm{H}_{5}\right), 7.88$ and $7.94(2 \times \mathrm{m}, 4 \mathrm{H}$, phthalimido group). ${ }^{13} \mathrm{C}$ NMR ( $\left.\mathrm{CD}_{3} \mathrm{OD}\right): \delta=27.13$ and 31.21 $\left(2 \times \mathrm{CH}_{3}\right), 57.53$ (6-C), 60.31 (10-C), 62.61 (2-C), 65.56 (5C), $68.72(3-\mathrm{C}), 71.32\left(\mathrm{O}-\mathrm{CH}_{2}-\mathrm{N}\right), 167.92,168.12,168.85$ and 173.62 (carbonyls). IR (KBr): $1790 \mathrm{~cm}^{-1}$ (ester $\mathrm{C}=\mathrm{O}$ stretch.), 1775 ( $\beta$-lactam $\mathrm{C}=\mathrm{O}$ stretch.), 1750, 1720 and 1705 (imide asym. and sym. $\mathrm{C}=\mathrm{O}$ stretch. + sidechain amide $\mathrm{C}=\mathrm{O}$ stretch.).

$\mathrm{N}$-Acetylampicillin, phthalimidomethyl ester. Triethylamine $(0.4 \mathrm{~mL}, 2.8 \mathrm{mmol})$ and acetic anhydride $(0.3 \mathrm{~mL}$, $3 \mathrm{mmol})$ were added to a suspension of $2(1 \mathrm{~g}, 2 \mathrm{mmol})$ in $\mathrm{CH}_{2} \mathrm{Cl}_{2}(20 \mathrm{~mL})$ at $0-5^{\circ} \mathrm{C}$. The reaction mixture was stirred at $0-5^{\circ} \mathrm{C}$ for $4 \mathrm{~h}$, washed with water, dried over magnesium sulfate and filtered. Ether was added to give a colourless solid. The solid was collected by filtration, washed with ether and dried over $\mathrm{P}_{2} \mathrm{O}_{5}$ in vacuo (yield, $0.9 \mathrm{~g}, 90 \%$ ), mp $126-128^{\circ} \mathrm{C}$. Elemental analysis $\mathrm{C}_{27} \mathrm{H}_{26}$ $\mathrm{N}_{4} \mathrm{O}_{7} \mathrm{~S} \cdot 0.75 \mathrm{H}_{2} \mathrm{O}$ : calcd C, 57.49, H, 4.91, N, 9.93; found $\mathrm{C}, 57.48, \mathrm{H}, 4.84, \mathrm{~N}, 9.93 .{ }^{1} \mathrm{H} \mathrm{NMR}\left(\mathrm{CDCl}_{3}\right): \delta=2.01(\mathrm{~s}$, $\left.3 \mathrm{H}, \mathrm{CH}_{3} \mathrm{CO}\right), 5.55\left(\mathrm{q}, J_{1}=4.2 \mathrm{~Hz}, J=8.7 \mathrm{~Hz}, 1 \mathrm{H}, 6-\mathrm{CH}\right)$, $5.64(\mathrm{~d}, J=6.9 \mathrm{~Hz}, 1 \mathrm{H}, 10-\mathrm{CH}), 6.85(\mathrm{~d}, J=6.9 \mathrm{~Hz}, 1 \mathrm{H}$, $10-\mathrm{CHN} H), 7.00(\mathrm{~d}, J=8.7 \mathrm{~Hz}, 1 \mathrm{H}, 6-\mathrm{CHN} H) .{ }^{13} \mathrm{C}$ NMR $\left(\mathrm{CDCl}_{3}\right): \delta=23.08\left(\mathrm{CH}_{3} \mathrm{CO}\right), 166.36,166.55,169.77$, 169.98 and 172.78 (carbonyls). IR (KBr): $1780 \mathrm{~cm}^{-1}$ (ester $+\beta$-lactam $\mathrm{C}=\mathrm{O}$ stretch.), 1755, 1730 and 1650 (imide + amides $\mathrm{C}=\mathrm{O}$ stretch.).

Cyclohexylidenesuccinimide (10). Maleimide (1.0 g, $10 \mathrm{mmol})$ and tri- $n$-butylphosphine $(2.1 \mathrm{~mL}, 10 \mathrm{mmol})$ in glacial acetic acid $(15 \mathrm{~mL})$ were heated at $80^{\circ} \mathrm{C}$ for $15 \mathrm{~min}$ and then left to stand for $1 \mathrm{~h}$. The solvent was evaporated at $50^{\circ} \mathrm{C}(10 \mathrm{~mm} \mathrm{Hg})$ and the residue coevaporated with toluene $(2 \times 20 \mathrm{~mL})$, leaving the ylid as a pink oily residue. Cyclohexanone $(5 \mathrm{~mL}, 50 \mathrm{mmol})$ and $\mathrm{K}_{2} \mathrm{CO}_{3}(1.38 \mathrm{~g}$, $10 \mathrm{mmol}$ ) were added. The mixture was heated at $100^{\circ} \mathrm{C}$ for $4 \mathrm{~h}$ and the excess of cyclohexanone was removed under vacuum $(1 \mathrm{~mm} \mathrm{Hg})$ to give a red residue. This residue was partitioned between water and $\mathrm{CH}_{2} \mathrm{Cl}_{2}$. The organic extract was dried $\left(\mathrm{MgSO}_{4}\right)$ and evaporated. The residue was crystallised in $\mathrm{C}_{2} \mathrm{H}_{5} \mathrm{OH}$ (yield $0.34 \mathrm{~g}, 20 \%$ ). Mp $166{ }^{\circ} \mathrm{C} .{ }^{1} \mathrm{H}$ NMR $\left(\mathrm{CDCl}_{3}\right) \delta=1.65(\mathrm{~m}, 6 \mathrm{H}), 2.16(\mathrm{t}$, $J=6 \mathrm{~Hz}, 2 \mathrm{H})$ and $2.98(\mathrm{t}, J=6.3 \mathrm{~Hz}, 2 \mathrm{H})($ cyclohexylidene substituent), 3.25 (s, $2 \mathrm{H}$, imide ring $\left.\mathrm{CH}_{2}\right), 8.62(1 \mathrm{H}, \mathrm{NH})$. ${ }^{13} \mathrm{C}$ NMR $\left(\mathrm{CDCl}_{3}\right): \delta=29.45$ (imide ring $\left.\mathrm{CH}_{2}\right), 116.41$ and 158.53 (olefinic Cs), 170.24 and 173.90 (imide carbonyls). IR (KBr): $3170 \mathrm{~cm}^{-1}, 3060$ (NH stretch.), 1750,1720 and $1710(\mathrm{C}=\mathrm{O}$ stretch. $), 1655(\mathrm{C}=\mathrm{C}$ stretch. $)$.
Exact mass: calcd for $\mathrm{C}_{10} \mathrm{H}_{13} \mathrm{NO}_{2}, 179.094629$; found, 179.094564 .

Cyclohexylidene- $N$-hydroxymethylsuccinimide (11). A mixture of cyclohexylidenesuccinimide ( $1 \mathrm{~g}, 6 \mathrm{mmol}), 20 \%$ aqueous formaldehyde $(10 \mathrm{~mL}, 66 \mathrm{mmol})$ and DMF (four drops) was heated at $100^{\circ} \mathrm{C}$ for $10 \mathrm{~min}$ with stirring, cooled and left to stand at room temperature. The white needles formed were collected, washed with water and dried over $\mathrm{P}_{2} \mathrm{O}_{5}$ (yield: $1.17 \mathrm{~g}, 100 \%$ ). $\mathrm{Mp} 157-159^{\circ} \mathrm{C} .{ }^{1} \mathrm{H}$ NMR $\left(\mathrm{CDCl}_{3}\right) \delta=3,69(\mathrm{t}, J=7.8 \mathrm{~Hz}, 1 \mathrm{H}, \mathrm{OH}), 5.05(\mathrm{~d}$, $\left.J=7.8 \mathrm{~Hz}, 2 \mathrm{H}, \mathrm{N}-\mathrm{CH}_{2}-\mathrm{O}\right) .{ }^{13} \mathrm{C} \mathrm{NMR}\left(\mathrm{CDCl}_{3}\right): \delta=29.7$ (imide ring $\left.\mathrm{CH}_{2}\right), 61.9\left(\mathrm{~N}-\mathrm{CH}_{2}-\mathrm{O}\right)$. Exact mass: calcd for $\mathrm{C}_{11} \mathrm{H}_{15} \mathrm{NO}_{3}, 209.105194$; found, 209.105114.

Cyclohexylidene- $N$-bromomethylsuccinimide (12). A suspension of the former compound $(0.4 \mathrm{~g}, 2 \mathrm{mmol})$, phosphorus tribromide $(0.52 \mathrm{~g}, 2 \mathrm{mmol})$ and toluene $(2 \mathrm{~mL})$ was refluxed for $4 \mathrm{~h}$. The solution was left to settle and the supernatant was poured out. The insoluble residue was triturated with hot toluene $(1-5 \mathrm{~mL})$. The solid obtained after evaporation under vacuum of the combined toluene solutions was triturated with dry ether $(3 \mathrm{~mL})$. The solution was filtered and the filtrate evaporated in vacuo to leave a yellowish solid (yield $0.35 \mathrm{~g}$, $70 \%) . \mathrm{Mp} 110^{\circ} \mathrm{C} .{ }^{1} \mathrm{H}$ NMR $\left(\mathrm{CDCl}_{3}\right) \delta=5.28(\mathrm{~s}, 2 \mathrm{H}$, $\left.\mathrm{N}-\mathrm{CH}_{2}-\mathrm{Br}\right) .{ }^{13} \mathrm{C}$ NMR $\left(\mathrm{CDCl}_{3}\right): \delta=30.73$ and 31.74 (imide ring $\mathrm{CH}_{2}$ and $\mathrm{N}-\mathrm{CH}_{2}-\mathrm{Br}$ ). Exact mass: calcd for $\mathrm{C}_{11} \mathrm{H}_{14} \mathrm{NO}_{2} \mathrm{Br}$, 271.020790; found, 271.021280.

Ampicillin cycohexylidenesuccinimidomethyl ester, hydrochloride (3). The same procedure was used as for compound 2. The yield was $60 \%$. Mp $176-177^{\circ} \mathrm{C}$. Elemental analysis $\mathrm{C}_{27} \mathrm{H}_{33} \mathrm{ClN}_{4} \mathrm{O}_{6} \mathrm{~S} \cdot 1.5 \mathrm{H}_{2} \mathrm{O}$ : calcd $\mathrm{C}, 53.68, \mathrm{H}, 6.01$, $\mathrm{N}, 9.27$; found $\mathrm{C}, 53.46, \mathrm{H}, 5.89, \mathrm{~N}, 9.25 .{ }^{1} \mathrm{H} \mathrm{NMR}$ $\left(\mathrm{CD}_{3} \mathrm{OD}\right): \delta=1.38$ and $1.41\left(2 \times \mathrm{s}, 6 \mathrm{H}, 2 \times \mathrm{CH}_{3}\right), 1.65(\mathrm{~m}$, $6 \mathrm{H}), 2.26(\mathrm{~m}, 2 \mathrm{H})$ and $3.03(\mathrm{~m}, 2 \mathrm{H})$ (cyclohexylidene substituent), 3.36 (s, $2 \mathrm{H}$, imide ring $\left.\mathrm{CH}_{2}\right), 4.38(\mathrm{~s}, 1 \mathrm{H}, 3-$ $\mathrm{CH}), 5.13(\mathrm{~s}, 1 \mathrm{H}, 10-\mathrm{CH}), 5.46(\mathrm{~d}, J=4.2 \mathrm{~Hz}, 1 \mathrm{H})$ and $5.57(\mathrm{~m}, 3 \mathrm{H})\left(5-\mathrm{CH}, 6-\mathrm{CH}\right.$ and $\left.\mathrm{O}-\mathrm{CH}_{2}-\mathrm{N}\right), 7.45-7.53$ $\left(2 \times \mathrm{m}, 5 \mathrm{H}, \mathrm{C}_{6} \mathrm{H}_{5}\right) \cdot{ }^{13} \mathrm{C}$ NMR $\left(\mathrm{CD}_{3} \mathrm{OD}\right): \delta=26.99$ and $27.14\left(2 \times \mathrm{CH}_{3}\right), 57.50(6-\mathrm{C}), 60.03(10-\mathrm{C}), 62.86$ (2-C), 65.57 (5-C), 68.69 (3-C), $71.31\left(\mathrm{O}-\mathrm{CH}_{2}-\mathrm{N}\right), 168.15$, $168.92,169.62,173.64$ and 174.78 (carbonyls). IR (KBr): $1800-1750 \mathrm{~cm}^{-1}$ (several unresolved bands) and 1700 (carbonyls $\mathrm{C}=\mathrm{O}$ stretch.), $1655(\mathrm{C}=\mathrm{C}$ stretch.).

4-(2-Diisopropylaminoethoxy)benzaldehyde (6a). 2-Diisopropylamino-ethyl chloride hydrochloride $(3.2 \mathrm{~g}$, $16 \mathrm{mmol}$ ) was partitioned between $5 \% \mathrm{Na}_{2} \mathrm{CO}_{3}$ ans $\mathrm{CH}_{2} \mathrm{Cl}_{2}$. The organic phase was dried on $\mathrm{MgSO}_{4}$, filtered and evaporated, leaving the free amine $(2.2 \mathrm{~g}, 84 \%)$. 4-Hydroxybenzaldehyde $(1.65 \mathrm{~g}, 13.5 \mathrm{mmol})$ was dissolved in absolute methanol $(120 \mathrm{~mL}$, dried on $\mathrm{Mg}$ ). Caesium carbonate $(2.28 \mathrm{~g}, 7 \mathrm{mmol})$ was added. After stirring for $20 \mathrm{~min}$ at room temperature, the solvent was evaporated under vacuum $\left(40^{\circ} \mathrm{C}, 3 \mathrm{~h}\right)$. The residue was dissolved in DMF (dried on $\mathrm{CaH}_{2}$ ), and the mixture was evaporated again to remove all traces of methanol. A second volume of DMF was added $(80 \mathrm{~mL})$, followed by diisopropylaminoethyl chloride $(2.2 \mathrm{~g}, 13.5 \mathrm{mmol})$. The mixture was heated at $65^{\circ} \mathrm{C}$ for $24 \mathrm{~h}$, then filtered. The filtrate was concentrated and distilled to give a colourless 
liquid (yield $2.4 \mathrm{~g}, 71 \%$ ). Bp $137-138^{\circ} \mathrm{C} / 0.9 \mathrm{~mm} \mathrm{Hg} \cdot{ }^{1} \mathrm{H}$ $\operatorname{NMR}\left(\mathrm{CDCl}_{3}\right): \delta=0.96\left(\mathrm{~d}, J=6.5 \mathrm{~Hz}, 12 \mathrm{H}, 4 \times \mathrm{CH}_{3}\right)$, $2.76\left(\mathrm{t}, J=7.3 \mathrm{~Hz}, 2 \mathrm{H}, \mathrm{CH}_{2}-\mathrm{N}\right), 2.96(\mathrm{~m}, 2 \mathrm{H}, \mathrm{CH}-\mathrm{N})$, $3.88\left(\mathrm{t}, J=7.3 \mathrm{~Hz}, 2 \mathrm{H}, \mathrm{CH}_{2}-\mathrm{O}\right), 6.91$ and $7.74(2 \times \mathrm{d}$, $\left.J=8.7 \mathrm{~Hz}, 4 \mathrm{H}, \mathrm{C}_{6} \mathrm{H}_{4}\right), 9.79$ (s, $\left.1 \mathrm{H}, \mathrm{CHO}\right) .{ }^{13} \mathrm{C} \mathrm{NMR}$ $\left(\mathrm{CDCl}_{3}\right): \delta=190.58$ (CHO). IR (film): $1690 \mathrm{~cm}^{-1}(\mathrm{C}=\mathrm{O}$ stretch.). Exact mass: calcd for $\mathrm{C}_{15} \mathrm{H}_{23} \mathrm{NO}_{2}, 249.172879$; found, 249.173264 .

[4 - ( 2 - Diisopropylaminoethoxy) benzylidene] succinimide (7a). Maleimide $(1.6 \mathrm{~g}, 16 \mathrm{mmol})$ and triphenylphosphine $(4.2 \mathrm{~g}, 16 \mathrm{mmol})$ were stirred in glacial acetic acid $(30 \mathrm{~mL})$ at $70^{\circ} \mathrm{C}$ for $0.5 \mathrm{~h}$. Ether was added. The ylid precipitated as a white solid. It was dried in vacuo over $\mathrm{P}_{2} \mathrm{O}_{5}$ (yield: $5.1 \mathrm{~g}, 14 \mathrm{mmol}, 89 \%$ ). This ylid, DMSO (30 mL) and 4-(2-diisopropylamino-ethoxy)benzaldehyde $(3.5 \mathrm{~g}, 14 \mathrm{mmol})$ were stirred at $80^{\circ} \mathrm{C}$ for $3 \mathrm{~h}$. A red coloration developed. DMSO was removed under reduced pressure at $60^{\circ} \mathrm{C}$, leaving a red glue. Trituration with dry ether gave a solid that was filtered and crystallised in $\mathrm{CH}_{2} \mathrm{Cl}_{2}$ (yield: $3.5 \mathrm{~g}, 76 \%$ ). $\mathrm{Mp} 160-162{ }^{\circ} \mathrm{C} .{ }^{1} \mathrm{H}$ NMR $\left(\mathrm{CDCl}_{3}\right): \delta=1.04\left(\mathrm{~d}, J=6.5 \mathrm{~Hz}, 12 \mathrm{H}, 4 \times \mathrm{CH}_{3}\right)$, $2.82\left(\mathrm{t}, J=7.3 \mathrm{~Hz}, 2 \mathrm{H}, \mathrm{CH}_{2}-\mathrm{N}\right), 3.04(\mathrm{~m}, J=6.5 \mathrm{~Hz}, 2 \mathrm{H}$, $\mathrm{CH}-\mathrm{N}), 3.56\left(\mathrm{~d}, J=2.3 \mathrm{~Hz}, 2 \mathrm{H}\right.$, imide ring $\left.\mathrm{CH}_{2}\right), 3.93(\mathrm{t}$, $\left.J=7.3 \mathrm{~Hz}, 2 \mathrm{H}, \mathrm{CH}_{2}-\mathrm{O}\right), 6.94$ and $7.40(2 \times \mathrm{d}, J=8.8 \mathrm{~Hz}$, $\left.4 \mathrm{H}, \mathrm{C}_{6} \mathrm{H}_{4}\right), 7.53(\mathrm{t}, J=2.3 \mathrm{~Hz}, 1 \mathrm{H}$, olefinic $\mathrm{H}) .{ }^{13} \mathrm{C} \mathrm{NMR}$ $\left(\mathrm{CDCl}_{3}\right): \delta=35.09$ (imide ring $\left.\mathrm{CH}_{2}\right), 121.06$ and 134.87 (olefinic carbons), 171.26 and 174.23 (imide carbonyls). IR (KBr) 1755 and $1705 \mathrm{~cm}^{-1}$ (C=O stretch.), 1645 $\left(\mathrm{C}=\mathrm{C}\right.$ stretch.). Exact mass: calcd for $\mathrm{C}_{19} \mathrm{H}_{26} \mathrm{~N}_{2} \mathrm{O}_{3}$, 330.194343; found, 330.194602.

[4-(2 - Diisopropylaminoethoxy)benzylidene]- $N$-hydroxymethylsuccinimide, hydrobromide (8a). The above described compound ( $2 \mathrm{~g}, 6 \mathrm{mmol})$ was dissolved by shaking $2 \mathrm{~h}$ at room temperature with one equivalent of $\mathrm{HBr}$ in water $(70 \mathrm{~mL})$. After filtration, water was evaporated under vacuum. The obtained white solid was washed with a large quantity of acetone (dried over $\left.\mathrm{K}_{2} \mathrm{CO}_{3}\right)$. It was dissolved in water $(7 \mathrm{~mL})$ at $80^{\circ} \mathrm{C}$. An equivalent of aqueous formaldehyde $(0.486 \mathrm{~g}, 37 \%$, $6 \mathrm{mmol}$ ) was added and the mixture was heated at $100{ }^{\circ} \mathrm{C}$ for $20 \mathrm{~min}$. Evaporation under vacuum gave a white solid that was crystallised in ethanol. The crystals were filtered, washed with acetone and dried over $\mathrm{P}_{2} \mathrm{O}_{5}$ (yield: $1.3 \mathrm{~g}, \quad 50 \%$ ). $\mathrm{Mp} \quad 207-208^{\circ} \mathrm{C} . \quad{ }^{1} \mathrm{H} \quad \mathrm{NMR}$ ([D $]$ DMSO): $\delta=4.83\left(2 \mathrm{H}, \mathrm{N}-\mathrm{CH}_{2}-\mathrm{O}\right), 6.35(1 \mathrm{H}, \mathrm{OH})$. ${ }^{13} \mathrm{C}$ NMR ([D $]$ DMSO): $\delta=33.61$ (imide ring $\mathrm{CH}_{2}$ ), $60.52\left(\mathrm{~N}-\mathrm{CH}_{2}-\mathrm{O}\right)$. Elemental analysis $\mathrm{C}_{20} \mathrm{H}_{29} \mathrm{BrN}_{2} \mathrm{O}_{4}$ : calcd C, 54.42, H, 6.62, N, 6.35; found C, 54.35, H, 6.84, N, 6.37 .

[4-(2-Diisopropylaminoethoxy)benzylidene]- $\boldsymbol{N}$-bromomethylsuccinimide, hydrobromide (9a). A mixture of the above described compound $(0.6 \mathrm{~g}, 1.36 \mathrm{mmol}), \mathrm{ClCH}_{2}-$ $\mathrm{CHCl}_{2}\left(3.5 \mathrm{~mL}\right.$, dried over $\left.\mathrm{P}_{2} \mathrm{O}_{5}\right)$ and $\mathrm{PBr}_{3}(1.2 \mathrm{~mL}$, $12.7 \mathrm{mmol}$ ) was heated at $120^{\circ} \mathrm{C}$ for $4 \mathrm{~h}$. The hot mixture was filtered and evaporated under reduced pressure, leaving a yellow solid that was dried over $\mathrm{P}_{2} \mathrm{O}_{5}$. It was crystallised in $\mathrm{CH}_{2} \mathrm{Cl}_{2}$ (yield: $0.4 \mathrm{~g}, 59 \%$ ). Mp 207$209^{\circ} \mathrm{C}$. ${ }^{1} \mathrm{H}$ NMR $\left(\mathrm{CDCl}_{3}\right): \delta=5.34$ (s, 2H, N-CH $\left.-\mathrm{Br}\right)$. ${ }^{13} \mathrm{C} \mathrm{NMR}\left(\mathrm{CDCl}_{3}\right): \delta=30.89$ and 34.07 (imide ring $\mathrm{CH}_{2}$ and $\mathrm{N}-\mathrm{CH}_{2}-\mathrm{Br}$ ).
Ampicillin, [4-(2-diisopropylaminoethoxy)benzylidene]succinimidomethyl ester, hydrochloride, (4a). Ampicillin trihydrate $(0.24 \mathrm{~g}, 0.6 \mathrm{mmol})$ was alkylated as described for $\mathbf{2}$, i.e. protected by benzaldehyde and esterified. The ester was extracted in ethyl acetate and then deprotected. When the aqueous deprotection mixture (freed from acetonitrile by partial evaporation) was saturated with sodium chloride, a yellow gum appeared. It was washed with dry ether and dried over $\mathrm{P}_{2} \mathrm{O}_{5}(0.3 \mathrm{~g}, 65 \%)$. The solid so formed was triturated with isopropanol (dried over $\mathrm{MgSO}_{4}$ ) and the mixture was filtered on an HPLC filter (Millipore, HVHP, $0.45 \mu \mathrm{m}$ ) to remove sodium chloride. Isopropanol was partially evaporated under vacuum. A suspension was obtained, that was again filtered on an HPLC filter. This solution was evaporated, giving a solid that was dried over $\mathrm{P}_{2} \mathrm{O}_{5}$. Mp $170-172{ }^{\circ} \mathrm{C}$. Elemental analysis $\mathrm{C}_{36} \mathrm{H}_{47} \mathrm{Cl}_{2} \mathrm{~N}_{5} \mathrm{O}_{7} \mathrm{~S} \cdot 2.8 \mathrm{H}_{2} \mathrm{O}$ : calcd $\mathrm{C}$, 53.04, H, 6.50, N, 8.59; found, C, 53.04, H, 6.38, N, 8.49. ${ }^{1} \mathrm{H}$ NMR $\left(\mathrm{CD}_{3} \mathrm{OD}\right): \delta=1.61-1.66$ (multiplet, 18 $\left.\mathrm{H}, 6 \times \mathrm{CH}_{3}\right), 3.88\left(\mathrm{t}, \mathrm{J}=4.7 \mathrm{~Hz}, 2 \mathrm{H}, \mathrm{OCH}_{2} \mathrm{CH}_{2} \mathrm{~N}\right), 3.92$ (d, $J=1.8 \mathrm{~Hz}$ (allylic coupling), $2 \mathrm{H}$, succinimide ring $\left.\mathrm{CH}_{2}\right), 4.05(\mathrm{~m}, J=6.5 \mathrm{~Hz}, 2 \mathrm{H}$, isopropyl CHs), 4.60 (s, $1 \mathrm{H}, 3-\mathrm{CH}), 4.64\left(\mathrm{t}, J=4.7 \mathrm{~Hz}, 2 \mathrm{H}, \mathrm{OCH}_{2} \mathrm{CH}_{2} \mathrm{~N}\right), 5.31$ $(\mathrm{s}, 1 \mathrm{H}, 10-\mathrm{CH}), 5.67$ and $5.77(2 \times \mathrm{d}, J=4.0 \mathrm{~Hz}, 2 \mathrm{H}, 5-$ and 6-CH), $5.86\left(\mathrm{~s}, 2 \mathrm{H}, \mathrm{OCH}_{2} \mathrm{~N}\right), 7.33(\mathrm{~d}, J=8.8 \mathrm{~Hz}$, $2 \mathrm{H})$ and $7.44-7.62$ (8H, 3 multiplets) $\left(\mathrm{C}_{6} \mathrm{H}_{5}, \mathrm{C}_{6} \mathrm{H}_{4}\right.$ and olefinic $\mathrm{CH}) .{ }^{13} \mathrm{C} \mathrm{NMR}\left(\mathrm{CD}_{3} \mathrm{OD}\right): \delta=17.38$ and 19.09 (diastereotopic isopropyl $\mathrm{CH}_{3} \mathrm{~s}$ ), 27.18 and 31.22 $\left(2 \times \mathrm{CH}_{3}\right.$ on the thiazolidine ring), 34.86 (imide ring $\mathrm{CH}_{2}$ ), 57.53 (6-C), 60.34 (10-C), 63.09 (2-C), 65.61 (5C), $68.74(3-\mathrm{C}), 71.36\left(\mathrm{O}-\mathrm{CH}_{2}-\mathrm{N}\right), 168.11,168.91$, 171.19, 173.63 and 174.83 (carbonyls). IR (KBr) 1775 $\mathrm{cm}^{-1}$ and 1710 ( $\mathrm{C}=\mathrm{O}$ stretch.), 1640 ( $\mathrm{C}=\mathrm{C}$ stretch.).

[4 - (3 - Dimethylaminopropoxy) benzylidene]succinimide (7b). The same procedure was used as for the diisopropyl analogue, except that $\mathrm{CHCl}_{3}$ was used as a solvent for the Wittig reaction instead of DMSO. Yield: $73 \%$. $\mathrm{Mp} 187.0-189^{\circ} \mathrm{C}$. ${ }^{1} \mathrm{H} \mathrm{NMR}\left(\mathrm{CDCl}_{3}\right.$ and $\left.\mathrm{CF}_{3} \mathrm{COOH}\right)$ : $\delta=2.30\left(\mathrm{~m}, 2 \mathrm{H}, \mathrm{NCH}_{2} \mathrm{CH}_{2} \mathrm{CH}_{2} \mathrm{O}\right), 3.03(\mathrm{~d}, J=5.0 \mathrm{~Hz}$, $\left.6 \mathrm{H}, 2 \times \mathrm{CH}_{3}\right), 3.45\left(\mathrm{~m}, 2 \mathrm{H}, \mathrm{CH}_{2}-\mathrm{N}\right), 3.68(\mathrm{~s}, 2 \mathrm{H}$, imide ring $\left.\mathrm{CH}_{2}\right), 4.16\left(\mathrm{t}, 2 \mathrm{H}, \mathrm{CH}_{2}-\mathrm{O}\right), 6.91$ and $7.43(2 \times \mathrm{d}$, $\left.J=8.5 \mathrm{~Hz}, 4 \mathrm{H}, \mathrm{C}_{6} \mathrm{H}_{4}\right), 7.64(\mathrm{~s}, 1 \mathrm{H}$, olefinic $\mathrm{CH}) .{ }^{13} \mathrm{C}$ NMR $\left(\mathrm{CDCl}_{3}\right.$ and $\left.\mathrm{CF}_{3} \mathrm{COOH}\right): \delta=34.79$ (imide ring $\mathrm{CH}_{2}$ ), 120.47 and 136.67 (olefinic carbons), 173.11 and 176.04 (imide carbonyls). IR (KBr): $1740 \mathrm{~cm}^{-1}$ and 1700 ( $\mathrm{C}=\mathrm{O}$ stretch.), 1650 ( $\mathrm{C}=\mathrm{C}$ stretch.). Exact mass: calcd for $\mathrm{C}_{16} \mathrm{H}_{20} \mathrm{~N}_{2} \mathrm{O}_{3}, 288.147393$; found, 288.146918 .

[4 - (3 - Dimethylaminopropoxy)benzylidene] - $N$ - hydroxymethylsuccinimide, hydrobromide (8b). The $\mathrm{HBr}$ salt of the former compound was obtained by dissolution in trifluoroacetic acid, treatment with one equivalent of concentrated aqueous $\mathrm{HBr}$ and evaporation. The residual solid was washed with ether. The same reaction procedure was then used as for the diidopropyl analogue. Yield $59 \%$. Mp $198^{\circ} \mathrm{C} .{ }^{1} \mathrm{H}$ NMR ([D $]$ DMSO): $\delta=4.86(\mathrm{~d}$, $\left.J=6.5 \mathrm{~Hz}, 2 \mathrm{H}, \mathrm{N}-\mathrm{CH}_{2}-\mathrm{O}\right), 6.38(\mathrm{t}, J=6.5 \mathrm{~Hz}, 1 \mathrm{H}, \mathrm{OH})$. ${ }^{13} \mathrm{C}$ NMR ([D 6 DMSO): $\delta=33.86$ (imide ring $\mathrm{CH}_{2}$ ), 60.73 $\left(\mathrm{N}-\mathrm{CH}_{2}-\mathrm{O}\right)$. Elemental analysis $\mathrm{C}_{17} \mathrm{H}_{23} \mathrm{BrN}_{2} \mathrm{O}_{4}$ : calcd C, 51.14, H, 5.81, N, 7.02; found C, 51.04, H, 5.97, N, 7.09 . 
[4-(3-Dimethylaminopropoxy)benzylidene]- $N$-bromomethylsuccinimide, hydrobromide (9b). The procedure was the same as for the diisopropyl analogue, except that acetonitrile (dried over $\mathrm{P}_{2} \mathrm{O}_{5}$ ) was used as a solvent instead of trichloroethane. Yield $69 \%$. Mp $224-225^{\circ} \mathrm{C}$. ${ }^{1} \mathrm{H}$ NMR $\left(\mathrm{CDCl}_{3}\right): \delta=5.35\left(\mathrm{~s}, 2 \mathrm{H}, \mathrm{N}-\mathrm{CH}_{2}-\mathrm{Br}\right) \cdot{ }^{13} \mathrm{C}$ NMR $\left(\mathrm{CDCl}_{3}\right): \delta=30.90$ and $34.12\left(\mathrm{~N}-\mathrm{CH}_{2}-\mathrm{Br}\right.$ and imide ring $\mathrm{CH}_{2}$ ).

\begin{abstract}
Ampicillin [4 - (3 - dimethylaminopropoxy)benzylidene]succinimidomethyl ester, hydrochloride (4b). Ampicillin trihydrate $(0.27 \mathrm{~g}, 0.67 \mathrm{mmol})$ was alkylated as described for $\mathbf{4 a}$ and the product was isolated in the same way. Yield $62 \%$. Mp $188-190^{\circ} \mathrm{C}$. Elemental analysis $\mathrm{C}_{33} \mathrm{H}_{41} \mathrm{Cl}_{2} \mathrm{~N}_{5}$ $\mathrm{O}_{7} \mathrm{~S} \cdot 2 \mathrm{H}_{2} \mathrm{O}$ : calcd $\mathrm{C}, 52.24, \mathrm{H}, 5.98, \mathrm{~N}, 9.23$; found $\mathrm{C}$, $52.15, \mathrm{H}, 5.89, \mathrm{~N}, 8.85 .{ }^{1} \mathrm{H}$ NMR $\left(\mathrm{CD}_{3} \mathrm{OD}\right): \delta=1.14$ and $1.17\left(2 \times \mathrm{s}, 2 \times 3 \mathrm{H}, 2 \times \mathrm{CH}_{3}\right), 2.28\left(\mathrm{~m}, 2 \mathrm{H}, \mathrm{OCH}_{2}\right.$ $\left.\mathrm{CH}_{2} \mathrm{CH}_{2} \mathrm{~N}\right), 2.95\left(\mathrm{~s}, 6 \mathrm{H}, \mathrm{N}\left(\mathrm{CH}_{3}\right)_{2}\right), 3.38(\mathrm{t}, J=7.9 \mathrm{~Hz}$, $\left.2 \mathrm{H}, \mathrm{OCH}_{2} \mathrm{CH}_{2} \mathrm{CH}_{2} \mathrm{~N}\right), 3.69$ (s, $2 \mathrm{H}$, succinimide ring $\left.\mathrm{CH}_{2}\right), 4.19\left(\mathrm{t}, J=5.6 \mathrm{~Hz}, 2 \mathrm{H}, \mathrm{OCH}_{2} \mathrm{CH}_{2} \mathrm{CH}_{2} \mathrm{~N}, 4.39\right.$ (s, $1 \mathrm{H}, 3-\mathrm{CH}), 5.11(\mathrm{~s}, 1 \mathrm{H}, 10-\mathrm{CH}), 5.45$ and $5.56(2 \times \mathrm{d}$, $J=3.9 \mathrm{~Hz}, 2 \times 1 \mathrm{H}, 5-$ and $6-\mathrm{CH}), 5.64\left(\mathrm{~s}, 2 \mathrm{H}, \mathrm{O}-\mathrm{CH}_{2}-\mathrm{N}\right)$, $7.07(\mathrm{~d}, J=8.6 \mathrm{~Hz}, 2 \mathrm{H})$ and $7.45-7.58(\mathrm{~m}, 8 \mathrm{H})\left(\mathrm{C}_{6} \mathrm{H}_{5}\right.$, $\mathrm{C}_{6} \mathrm{H}_{4}$ and olefinic $\left.\mathrm{CH}\right) .{ }^{13} \mathrm{C}$ NMR $\left(\mathrm{CD}_{3} \mathrm{OD}\right): \delta=25.67$ $\left(\mathrm{OCH}_{2} \mathrm{CH}_{2} \mathrm{CH}_{2} \mathrm{~N}\right), 27.17$ and $31.22\left(2 \times \mathrm{CH}_{3}\right), 34.86$

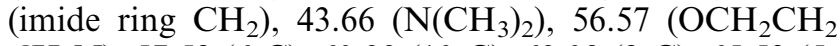
$\left.\mathrm{CH}_{2} \mathrm{~N}\right), 57.52$ (6-C), 60.33 (10-C), 63.08 (2-C), 65.59 (5C), $66.26\left(\mathrm{OCH}_{2} \mathrm{CH}_{2} \mathrm{CH}_{2} \mathrm{~N}\right), 68.72(3-\mathrm{C}), 71.35(\mathrm{O}-$ $\left.\mathrm{CH}_{2}-\mathrm{N}\right), 168.11,168.89,171.22,173.61$ and 174.87 (carbonyls). IR (KBr) $1770 \mathrm{~cm}^{-1}$ and $1710 \quad(\mathrm{C}=\mathrm{O}$ stretch.), 1635 (C=C stretch.).
\end{abstract}

Diampicillylmethane, dihydrochloride (5). Potassium bicarbonate $(0.496 \mathrm{~g}, 4.96 \mathrm{mmol})$ and benzaldehyde $(1 \mathrm{~mL}$, $9.92 \mathrm{mmol}$ ) were added to a suspension of ampicillin trihydrate $(2 \mathrm{~g}, 4.96 \mathrm{mmol})$ in DMF $(20 \mathrm{~mL})$. The mixture was stirred at $0-4{ }^{\circ} \mathrm{C}$ for $12 \mathrm{~h}$. Anhydrous magnesium sulfate $(2.4 \mathrm{~g}, 19.9 \mathrm{mmol})$ was added and the mixture was further stirred for $2-3 \mathrm{~h}$. The reaction mixture was left at $4{ }^{\circ} \mathrm{C}$ for 9 days, after the addition of $\mathrm{CH}_{2} \mathrm{I}_{2}(4 \mathrm{~mL}$, $49.6 \mathrm{mmol}$ ) and of a further amount of potassium bicarbonate $(0.496 \mathrm{~g}, 4.96 \mathrm{mmol})$. Evaporation of the mixture after filtration gave a yellow solid that was washed with ether, dried over $\mathrm{P}_{2} \mathrm{O}_{5}$, dissolved in ethyl acetate and submitted to flash-chromatography $(100 \mathrm{~g}$ of silica, eluent: ethyl acetate, $R_{\mathrm{f}}=0.85$ ). The obtained bispyrazolidinone was deprotected at $\mathrm{pH} 2.5$ as described for 2. The precipitation with sodium chloride gave a gum. After the brine was poured out, the gum was washed with ether and dried in vacuo over $\mathrm{P}_{2} \mathrm{O}_{5}$. The resulting powder was purified by dissolution in isopropanol as described for 4a. Yield: $36 \%$. Mp $190-191^{\circ} \mathrm{C}$. Elemental analysis $\mathrm{C}_{33} \mathrm{H}_{40} \mathrm{Cl}_{2} \mathrm{~N}_{6} \mathrm{O}_{8} \mathrm{~S}_{2} \cdot 1.5 \mathrm{H}_{2} \mathrm{O}$ : calcd $\mathrm{C}, 48.89, \mathrm{H}, 5.35, \mathrm{~N}$, 10.36; found $\mathrm{C}, 49.00, \mathrm{H}, 5.36, \mathrm{~N}, 10.09$. ${ }^{1} \mathrm{H}$ NMR (CD $\mathrm{OD}): \delta=1.39$ and $1.45\left(2 \times \mathrm{s}, 12 \mathrm{H}, 4 \times \mathrm{CH}_{3}, 4.41(\mathrm{~s}\right.$, $2 \mathrm{H}, 3-\mathrm{CH}), 5.08(\mathrm{~s}, 2 \mathrm{H}, 10-\mathrm{CH}), 5.46$ and $5.57(2 \times \mathrm{d}$, $J=4.0 \mathrm{~Hz}, 2 \times 2 \mathrm{H}, 5-$ and $6-\mathrm{CH}), 5.86\left(\mathrm{~s}, 2 \mathrm{H}, \mathrm{O}-\mathrm{CH}_{2}-\mathrm{O}\right.$, $7.47\left(\mathrm{~m}, 10 \mathrm{H}, \mathrm{C}_{6} \mathrm{H}_{5}\right) \cdot{ }^{13} \mathrm{C} \mathrm{NMR}\left(\mathrm{CD}_{3} \mathrm{OD}\right): \delta=27.18$ and $31.10\left(4 \times \mathrm{CH}_{3}\right), 57.53(6-\mathrm{C}), 60.32(10-\mathrm{C}), 65.47$ (5-C), 68.71 and 71.31 (2-C and 3-C), $81.61\left(\mathrm{O}-\mathrm{CH}_{2}-\mathrm{O}\right), 129.47$, $130.39,131.14,133.93\left(\mathrm{C}_{6} \mathrm{H}_{5}\right), 167.80,168.94$ and 173.60 (carbonyls). IR (KBr): $1770 \mathrm{~cm}^{-1}$ (ester and $\beta$ lactam $\mathrm{C}=\mathrm{O}$ stretch.), 1685 (amide $\mathrm{C}=\mathrm{O}$ stretch.).

\section{Acknowledgements}

I. Paternotte had a fellowship of the Belgian Fonds pour la Formation à la Recherche dans l'Industrie et dans l'Agriculture. This work was supported by the Belgian Fonds National de la Recherche Scientifique (grant no. 1.5113.00), the Belgian Fonds de la Recherche Scientifique Médicale (grant no. 3.4516.94) and the Fonds Spécial de Recherche from the Université Catholique de Louvain. We thank Professor E. De Hoffmann for his help in mass spectroscopy. We also thank the Leo Pharmaceutical Products Co., Denmark, for the gracious gift of pivampicillin.

\section{References and Notes}

1. Fan, H. J.; Paternotte, I.; Vermander, M.; Li, K.; Beaujean, M.; Scorneaux, B.; Dumont, P.; Osinski, P.; Claesen, M.; Tulkens, P. M.; Sonveaux, E. Bioorg. Med. Chem. Lett. 1997, 7, 3107 .

2. van den Broek, P. J. Rev. Infect. Dis. 1989, 11, 213.

3. Tulkens, P. M. Eur. J. Clin. Microbiol. Infect. Dis. 1991, 10, 100 .

4. Hamilton-Miller, J. M. T. Chemotherapia 1967, 12, 73.

5. Agersborg, H. P. K.; Batchelor, A.; Cambridge, G. W.; Rule, A. W. Brit. J. Pharmacol. 1966, 26, 649.

6. Nielsen, N. M.; Bundgaard, H. J. Pharm. Pharmacol. 1988, 40, 506.

7. Toney-Parker, T. E.; Notari, R. E. Drug Stab. 1995, 1, 40. 8. Fujiwara, H.; Kawashima, S. Chem. Pharm. Bull. 1985, 33, 1202.

9. Nguyen, N.-A. T.; Mortada, L. M.; Notari, R. E. Pharm. Res. 1988, 5, 288.

10. Connors, K. A.; Amidon, G. L.; Stella, V. J. In Chemical Stability of Pharmaceuticals, a Handbook for Pharmacists; J. Wiley \& Sons: New York, 1986; pp 198-207, 274-283.

11. Proctor, P.; Gensmantel, N. P.; Page, M. I. J. Chem. Soc. Perkin Trans. II 1982, 1185.

12. Laws, A. P.; Layland, N. J.; Proctor, D. G.; Page, M. I. J. Chem. Soc., Perkin Trans. II 1993, 17.

13. Vanwetswinkel, S.; Carlier, V.; Marchand-Brynaert, J.; Fastrez, J. Tetrahedron Lett. 1996, 37, 2761.

14. Moreira, R.; Calheiros, T.; Cabrita, J.; Mendes, E.; Pimentel, M.; Iley, J. Pharm. Res. 1996, 13, 70.

15. Saari, W. S.; Freedman, M. B.; Hartman, R. D.; King, S. W.; Raab, A. W.; Randall, W. C.; Engelhardt, E. L.; Hirschmann, R.; Rosegay, A.; Ludden, C. T.; Scriabine, A. J. Med. Chem. 1978, 21, 746.

16. de Duve, C. T.; de Barsy, T.; Poole, B.; Trouet, A.; Tulkens, P.; Van Hoof, F. Biochem. Pharmacol. 1974, 23, 249524.

17. Hedaya, E.; Theodoropulos, S. Tetrahedron 1968, 24, 2241.

18. Carey, F. A.; Sundberg, R. J. In Advanced Organic Chemistry; Plenum Press: New York, 1983; Vol. B, pp 71-73.

19. March, J. In Advanced Organic Chemistry, Reactions, Mechanisms and Structure; J. Wiley \& Sons: New York, 1992; p 960

20. Silverstein, R. M.; Clayton Bassler, G.; Morrill, T. C. In Spectrometric Identification of Organic Compounds; J. Wiley \& Sons: New York, 1991; p 215.

21. Johansen, M.; Bundgaard, H. Arch. Pharm. Chem. Sci. Ed. 1979, 7, 175.

22. Bird, A. E.; Steele, B. R.; Boles, M. O.; Gane, P. A. C. J. Chem. Soc., Perkin Trans. I 1982, 563. 
23. Hardcastle Jr., G. A.; Johnson, D. A.; Panetta, C. A. J. Org. Chem. 1966, 897.

24. Klixbüll, U.; Bundgaard, H. Int. J. Pharmaceutics 1985, 23, 163.

25. Bundgaard, H.; Klixbüll, U. Int. J. Pharmaceutics 1985, $27,175$.
26. Bird, A. E.; Cutmore, E. A.; Jennings, K. R.; Marshall, A. C. J. Pharm. Pharmacol. 1983, 35, 138.

27. Robinson-Fuentes, V. A.; Jefferies, T. M.; Branch, S. K. J. Pharm. Pharmacol. 1997, 49, 843.

28. Bundgaard, H.; Hansen, J. Int. J. Pharmaceutics 1981, 9, 273 